\title{
The effect of internal marketing on organisational commitment among retail bank managers
}

\author{
Albert Caruana \\ Department of M arketing, University of Malta, M sida, Malta \\ Peter Calleya \\ Mid-Med Bank Ltd PIc, Valletta, Malta
}

This paper examines internal processes associated with delivering customer satisfaction focusing particularly on the relationship between the nature and extent of internal marketing and its outcome in terms of the level of organisational commitment on the part of employees. The concepts of internal marketing and organisational commitment are discussed, suitable measures are identified and research is conducted among managers of a retail bank. The findings confirm a significant relationship between internal marketing and organisational commitment. The relationship of internal marketing is most significant with the affective dimension of organisational commitment. Limitations of the research are noted and directions for future research are indicated.

International J ournal of Bank Marketing

16/ 3 [1998] 108-116

(c) MCB University Press

[ISSN 0265-2323]

\section{Introduction}

In general, the marketing of physical products has focused on external customers. Often the implementation of marketing has been achi eved by adopting a for $m$ of organisation that includes a marketing department. This has frequently been organised along brand/ product management lines with brand managers responsible for the implementation of marketing plans. Until fairly recently, customers were only seen to be those that are external to the organisation and indeed many managers would have argued that it is difficult enough to get the marketing to exter nal customers right without adding more customers. Since around the mi ddle of the 1980s services marketing has established itself as an important area of study (Fisk et al., 1993). Authors looking at the marketing of service products have particularly highlighted the importance of inter nal customers.

Given the inseparability characteristic of services, contact people become crucial in the formulation of the product which the customer receives. It ther efore becomes clear that making promises to external customers, as is the case wi th the marketing of physical products, is not sufficient. The promises made about a service must be kept and it is only the employees of service fir ms that can do so. Service employees are so critical because the product being provided is a perfor mance (L ovel ock, 1983). The importance of the interaction process between the contact persons of the organisation and external customers has been highlighted by a number of authors. J an Carlzon (1987) of Scandinavian A irlines fame was perhaps one of the first to recognise their importance in the 1980s, refer ring to them almost emoti onally as the "moments of truth" for the organisation. Undoubtedly in the marketing of services this interactive process is a crucial aspect as it enables the devel opment of longter $m$ relationships thereby assuring customer retention and long-ter m success.

It becomes clear that successful marketing can only be implemented if the firm is involved not only in external but also in internal marketing. The successful service company must first sell the job to employees before it can sell its services to customers (Sasser, 1976). The objective of internal marketing is to create an inter nal environment in which customer consciousness proliferates among personnel. The sati sfaction of inter nal customers is important to the success of a service fir m (cf. Gremler et al., 1994). Indeed Rosenblunth and Peters (1992) have gone as far as arguing that the needs of the customers should come second to those of employees, as customer needs will only be successfully met after those of employees have been sati sfactorily met. One of the important consequences of internal marketing is to increase the organisational commitment of employees (Tansuhai et al., 1991). This in tur $n$ should result in increased job satisfaction, increased job performance and lower turnover of staff (J enkins and Thomlinson, 1992; Mathieu and Zajac, 1990; Schlessenger and Haskett, 1991) thereby facilitating the interactive process.

This study sets out to consi der what internal marketing involves and whether inter nal marketing practice in a service firm has an effect on the level of employee commitment to the organisation. The concepts of internal marketing and organisational commitment are first examined and the inter relationships are investigated. Results of a survey relating the levels of internal marketing and organisati onal commitment among managers of a retail bank are reported. Findings are discussed, implications are drawn and suggestions made for ongoing research.

\section{Internal marketing}

The internal marketing concept holds that the organisati on's personnel are the first market of a company. The main objective of the inter nal marketing function is to obtain motivated and customer consci ous per sonnel at every level (George, 1990; George and Grönross, 1989; Grönross, 1981). Grönross (1981) distingui shes between the implementation of inter nal marketing at the strategic and tactical level. At the strategi c level it should create an inter nal environment that bolsters customer consciousness and sales mindedness among employees. The key facilitators are here seen to be supporting management methods, personnel policy, 
Albert Caruana and

Peter Calleya

The effect of internal marketing on organisational commitment among retail bank managers

International Journal of

Bank Marketing

16/ 3 [1998] 108-116 internal trai ning and planning procedures. On the tactical level, the aim is to sell services, campaigns and other marketing efforts and initiatives to the personnel. Once the empl oyee is also seen as a customer it is possible to talk of an inter nal market. The internal market of employees is best motivated for service-mindedness and customer oriented behaviour by an active, marketing-like approach, where a variety of activities are used internally in an active, marketing-like and co-or di nated way (George, 1990; Grönross, 1984). The thinking underlying internal marketing is that employees are vi ewed as internal customers and jobs as inter nal products. J ob products must attract, develop and motivate employees ther eby satisfying the needs and wants of these internal customers while addressing the overall objectives of the organisation (Berry, 1981; Berry and Parasuraman, 1991). Si milarly, Kotler (1991) defines internal marketing as "the task of successfully hiring, trai ning and motivating able employees to serve the customer well". In this respect it represents el ements of good human resources management (HRM) (Bateson, 1991). Rafiq and A hmed (1993) note that few fir ms apply the internal marketing concept in practice and highlight how marketing techniques can be used to motivate employees. However, Hales (1994) is very critical of the application of inter nal marketing to HRM. He argues that internal marketing is unable to providea solid conceptual base emphasising, among others, the point that while HRM focuses on teamwork; internal marketing stresses individualism.

Money and Foreman (1996) providea matrix that offers an inter esting typology of internal marketing. The matrix consists of two dimensi ons that consider "who is the marketer" and "who is the customer". Each dimensi on can focus either on the department/group or the organisation. The most common situation encounter ed (Type IV) is where the organisation is both the marketer and the customer. However, the matrix provides three other possible situati ons; Typel is when the marketer is a department and the customer is another department; Type II is when the marketer is the organi sation and the customer is a department and Type III is when the marketer is a department and the customer is the organisati on. Such a typology can provide valuable insight into the role of inter nal marketing, the ways in which it can be used, as well as the circumstances under which it is appropriate. Money and Foreman (1996) focus on a Type IV situation and conceptualise the internal marketing concept along the lines suggested by Berry (1981), who insists that internal customers must be sold on the service and be happy in their jobs before they can effectively serve the final customer. Money and Foreman (1996) primarily operationalise their internal marketing construct by making use of the checklists subsequently provided by Berry (Berry et al., 1991; Berry and Parasuraman, 1991). The research by the authors indicate that the internal marketing construct consists of three factors that they term development, reward and vision. These closely mirror three of the essential aspects of internal marketing practices identified by Berry and Parasuraman (1991).

\section{Organisational commitment}

Organisational commitment involves the relative strength of an individual's identification with, and involvement in, a particular organisation. Here the employee is seen to be emotionally attached, identifies with the organisation, and is therefore committed to pursue its goals. Porter et al. (1974) conceptualised organisati onal commi tment as a unidimensional construct and proposed the organisational commitment questi onnaire to measure it. Many of the applications of organisational commitment in marketing have tended to use this conceptualisation (see, for example, J aworski and Kohli, 1993; Si guaw et al., 1994). Meyer and Allen (1984) refer to this aspect of organisational commitment as affective commi tment. However, basing themselves on si de-bet theory (cf. Becker, 1960) the authors identify a fur ther dimension of organisati onal commitment, which they ter m continuance commitment. This views the employee as being less affective and more calculative considering the costs that would result in ter ms of interests such as pensions and security. This type of commitment has been measured with scales developed by Ritzer and Trice (1969) whi ch were later amended by Hrebiniak and Alutto (1972). More recently, Allen and M eyer (1990) have added a fur ther dimension resulting in a conceptualisation of organi sati onal commitment that encompasses not only affective commitment and continuance commitment but also nor mative commitment. The latter refers to employees' feelings of obligation to stay with the organisation. Such feelings of obligation result from a process of internalisation of nor mative pressure ei ther prior or following affiliati on to an organisation. This conceptualisation of organi sational commitment led to the development of a $24 \mathrm{item}$ instrument, split into three sections, each of eight items, that capture all of the three dimensions (Allen and Meyer, 1990; Meyer and Allen, 1990; 1991). 
Albert Caruana and

Peter Calleya

The effect of internal marketing on organisational commitment among retail bank managers

International Journal of

Bank Marketing

16/ 3 [1998] 108-116
Internal marketing and organisational commitment

The major thrust of the inter nal marketing concept is to ensure that employees feel that management cares about them and thei $r$ needs are met. The successful application of the concept is translated into positive employee attitudes towards their work including organisati onal commitment, job involvement, work motivation and job satisfaction (Tansuhaj et al., 1991). There is some empirical support for a significant relationship between internal marketing and consumer satisfaction (Tansuhaj et al., 1987) and between internal marketing and service quality (Richardson and Robinson, 1986). The resultant positive effect of inter nal marketing will mean that employees will input maximum rather than mi nimum effort thereby better satisfying the needs and wants of external customers (Ber ry, 1981; Donnelly et al., 1985; George, 1990; Sasser and A rbeit, 1980).

Lack of commitment from employees can be harmful to an organisation, resulting in poorer performance arising from inferior service offerings and higher costs. Hogg (1996) has suggested that internal marketing could be the answer to gaining employee commitment, succeeding where traditional inter nal communications programmes have failed. Schlessenger and Heskett (1991) highlight the importance of motivated employees, arguing that thi s leads to a "cycle of success" that results in increased awareness of employees' roles in customer satisfaction; the integration of employees into winning teams; and a concentration on quality as the core of a service. These authors argue that management of service firms need to break out of a "cycle of failure". This is built on management toleration of dissatisfaction among employees involved in high contact si tuations with resulting high levels of turnover that in turn lead to a deteri or ati on of servi ce quality and ultimately long run decline of the organisation.

The marketing literature shows that market orientation is an antecedent to organisational commi tment. This is confirmed from research by J aworski and Kohli (1993) that conceptualises market orientation as consisting of three dimensions: intelligence gathering, intelligence di ssemination and responsiveness. Although in their study these authors have only used the affective commitment dimensi on to measure organi sational commitment, research using the expanded organisational commitment construct has also indicated that market orientation is only significantly rel ated to the affective component of organisati onal commitment
(Caruana et al., 1997). It is inter esting to note that market orientation like internal marketing consists of many activities that involve actions taken within the organisation. The psychology literature in particular highlights a number of other important antecedents to organisational commitment. The meta analysis by Mathi eu and Zajac (1990) summarises these under five main headings: role states, job characteristics, group/leader relations as well as personal and organisational characteristics. Similarly, in ter ms of consequences organisational commitment has been linked to vari ous aspects of job perfor mance (Mathieu and Zajac, 1990). However, increased job satisfaction and decreased tur nover intentions were found to be related only to the affective dimensi on (J enkins and Thomlinson, 1992).

Construct measures and data collection

To be able to investigate the relationship between internal marketing and organisational commitment, a research design was employed that involved inter nal postal questi onnaires to all managers of a retail bank. In arriving at a decision as to which instruments to use to capture the inter nal marketing and the organisati on commitment constructs consideration was given to the conceptualisations used as well as to the rigour with which the respective instruments were developed. Inter nal marketing was measured using the 15-item scale devel oped by Money and Foreman (1996). In operationalising the internal marketing construct these authors utilise focus group discussions with managers of service firms and the checklists on inter nal marketing from Berry and Parasuraman (1991) and Berry et al. (1991). They report results from two samples that provided reliability al phas (Cronbach, 1951) of 0.942 and 0.948 for inter nal marketing and of between 0.836 to 0.917 for vi si on, development and reward di mensi ons respectively. To measure organisational commitment use is made of the 24-item instrument devel oped by Allen and Meyer (1990). Thereliability of the scales measuring the three di mensions of organisational commitment ranged from 0.69 to 0.89 (Meyer and Allen, 1991) and confirmatory factor analysis has provided strong support for theinstrument which exhibits discriminant and convergent validity (Hackett et al., 1994). Moreover confir matory factor analysis by Dunham et al. (1994) indicates that the continuance commitment dimension sometimes splits into two sub-factors that have been ter med "personal sacrifice" and "lack of alter natives". Each item on both 
Albert Caruana and

Peter Calleya

The effect of internal marketing on organisational commitment among retail bank managers

International Journal of

Bank Marketing

16/ 3 [1998] 108-116 scales consi sted of 7-point scales with $1=$ "strongly disagree" and 7= "strongly agree". Higher scores on this scale indicate higher levels of internal marketing and organisati onal commitment. Classi ficatory variables in ter ms of age and gender were also collected. The final questionnai re was therefore made up of 41 items that consisted of measures for internal marketing, organisati onal commitment, together with two classificatory variables. Respondents were assured of complete anonymity and no names or other means of identification were requested.

A total of 267 internal postal questionnaires were sent to a random sample of half the population of managers of a retail bank. Managerial grades were chosen because these represent an important depository of knowledge for any organisation and are essential to the smooth oper ation of a bank. The survey was conducted during September 1996 and by the cut off date, three weeks later, a total of 171 usable replies were obtained, representing an effective response rate of 64 per cent. Given this relatively high response rate, no foll ow up reminders were thought necessary. The good response rates appear to have been, in part, a consequence of the interest that the subject matter generated (see Appendix).

\section{Analysis}

The mode for years of service was between 15 to 20 , and the percentage of females in the sample was 28 per cent. These were in line with that for the entire population of managers at the bank. These findings indicated suffi cient depth of the sample and the data could be checked for non-response bias. An "extrapolation procedure" was used to assess non-response bias. This assumes that "late" respondents are similar to the "theoretical" non-respondents (A rmstrong and Overton, 1977). No significant differences were found between the two sub samples when independent t-tests were used to deter mine whether significant differences existed between the means for the sum of the two constructs. Ther efore, the sample can be consi dered sufficient to draw conclusions about managers of the particular retail bank for the issues under study.

The mean, standard deviation and coefficient al pha (Cronbach, 1951) for each of the dimensions and overall for the two constructs was computed. Results for the entire inter nal marketing scale and organi sati onal commitment scal e together with their three respective dimensions in terms of reward, development and vision and affective, continuance and nor mative commi tment are presented in
Table I. All coefficient al phas are greater than 0.7 and therefore acceptable (Nunnally, 1978). In the case of the organisational commitment scale, its dimensions are much less correlated with only the affective and nor mative commitment exhibiting a significant relationship ( $r=0.419 ; p<0.001)$. This is in line with the results obtained by Allen and M eyer (1990). T wo aspects of vali dity were investigated. Nomological vali idity is indi cated in a factor analysis if items expected to load together actually do so, while evidence of discriminant validity is provided if the factors and their items are truly different from one another (Carman, 1990). Principal component factor analysis followed by a varimax rotation was perfor med in both instances and the items broadly loaded as expected providing support for both discriminant and nomological validity. The results appear in Tables II and III. Item 15 of the inter nal marketing scale is problematic as it does not load at all clearly. This is in line with earlier findings (M oney and Foreman, 1996) and may indicate that in future use of the measure it can probably be eliminated without loss.

Having established the psychometric proper ties of the two instruments, the relationship between the two constructs and their dimensions were investigated using multiple regression. To eliminate the possibility of intercorrelation, or thogonal factor regression scores were computed for each of the three dimensi ons in both the inter nal marketing and organisational commitment constructs. A total of eight models have been tested. In the first model the sum of the organisational commitment scale was used as the dependent variable in a multiple regression model with independent variables for the sum of the internal marketing scale together with those for age and gender. In the second model the independent variable for the sum of the inter nal marketing scale was replaced with the factor scores for the three dimensions of internal marketing and the multiple regression was recomputed. The first model resulted in a significant adjusted $\mathrm{R}^{2}$ of 0.185 , confirming that internal marketing activities do have a positive effect on organi sational commitment while the second model provi ded an adjusted $R^{2}$ of 0.189 and showed that all the three dimensions of internal marketing had a significant effect on organisational commitment (Table IV, columns 2 and 3 ). In the next three models each of the orthogonal factor scores of organisati onal commitment were each treated as the dependent variable in a regression equation with the sum of the inter nal marketing scale together with age and gender as independent variables. Results 
Albert Caruana and

Peter Calleya

The effect of internal marketing on organisational commitment among retail bank managers

International J ournal of

Bank Marketing

16/ 3 [1998] 108-116 here indicated that internal marketing had only a significant effect on the affective commitment dimension and provided an adjusted $\mathrm{R}^{2}$ of 0.305 (Table IV, column 4). In the last three models each of the orthogonal factor scores of organisational commi tment were treated as the dependent variable in a regressi on equati on with independent variables for the factor scores of the three dimensions of inter nal marketing together with age and gender. Results here indicated that the three dimensi ons of internal marketing only had a significant effect on the affective dimension of organisational commitment providing an adjusted $R^{2}$ of 0.310 (Table IV, column 5). In all models tested the variables for gender and age were not found to be significant.

\section{Conclusions}

The results highlight the important role of inter nal marketing in fostering organisational commitment. More importantly the research shows that the effect of internal marketing is on the affective commitment dimension and it is all the di mensions of inter nal marketing that are having an effect. A ffective commitment focuses on the emotional attachment of the employee to the organisation and underlines the commitment of the employee to pursue the goals of the organisation. Given the inseparability of the service provider from the product offering the importance of organisational commitment by employees cannot be stressed enough. The meta analysis by Mathieu and Zajac (1990) shows that age is normally an antecedent to organisational commitment but gender tends to have no effect. In this $\overline{\text { Table II }}$

Factor analysis of the items making up the internal marketing scales

\begin{tabular}{lccc}
\hline & \multicolumn{2}{c}{ Internal } & marketing dimensions \\
Item & Vision & Reward & Development \\
\hline Q1 & 0.83951 & 0.24438 & 0.22796 \\
Q2 & 0.85815 & 0.16098 & 0.18371 \\
Q3 & 0.32211 & 0.71883 & 0.26294 \\
Q4 & 0.12891 & 0.79282 & 0.15633 \\
Q5 & 0.07818 & 0.78010 & 0.18925 \\
Q6 & 0.51096 & 0.62128 & 0.14097 \\
Q7 & 0.35021 & 0.59790 & 0.32559 \\
Q13 & 0.05414 & 0.60559 & 0.54172 \\
Q14 & 0.19460 & 0.46817 & 0.58079 \\
Q15 & 0.51616 & 0.19014 & 0.49951 \\
Q8 & 0.49097 & 0.14683 & 0.63917 \\
Q9 & 0.20826 & 0.12763 & 0.76679 \\
Q10 & 0.37974 & 0.31335 & 0.67113 \\
Q11 & 0.36915 & 0.31044 & 0.63690 \\
Q12 & 0.02152 & 0.22651 & 0.78790 \\
\hline
\end{tabular}

research both elements have not been found to be significantly related to organi sational commi tment. The absence of a relationship with age is probably because the age range of the managerial grades in this study is fairly restricted.

Besides the variables highlighted in this research, organisational commitment has other antecedents. These include employees' perception of the extent to which jobs are challenging, roles and goals are clear, goals are challenging, management is receptive to employee suggesti ons, peer cohesion, organi sational dependability; employees are treated equitably and made to feel important, feedback about their work perfor mance is

$\overline{\text { Table I }}$

Mean and standard deviation, correlation matrix and reliabilities of constructs and dimensions in the study $(n=171)$

\begin{tabular}{|c|c|c|c|c|c|c|c|c|c|c|}
\hline & Mean & $\begin{array}{l}\text { Std } \\
\text { dev }\end{array}$ & Vision & Reward & Development & $\begin{array}{l}\text { Internal } \\
\text { marketing }\end{array}$ & $\begin{array}{c}\text { Affective } \\
\text { commitment }\end{array}$ & $\begin{array}{l}\text { Continuance } \\
\text { commitment }\end{array}$ & $\begin{array}{l}\text { Normative } \\
\text { commitment }\end{array}$ & $\begin{array}{l}\text { Organisational } \\
\text { commitment }\end{array}$ \\
\hline Vision & 7.37 & 2.57 & 0.859 & 0.568 & 0.581 & 0.718 & 0.390 & 0.071 & 0.149 & 0.310 \\
\hline Reward & 15.64 & 6.05 & & 0.885 & 0.715 & 0.892 & 0.475 & -0.016 & 0.211 & 0.343 \\
\hline $\begin{array}{l}\text { Development } \\
\text { Internal }\end{array}$ & 32.95 & 8.54 & & & 0.868 & 0.940 & 0.595 & 0.018 & 0.253 & 0.442 \\
\hline $\begin{array}{l}\text { marketing } \\
\text { Affective }\end{array}$ & 55.96 & 15.28 & & & & 0.927 & 0.586 & 0.016 & 0.250 & 0.435 \\
\hline $\begin{array}{l}\text { commitment } \\
\text { Continuance }\end{array}$ & 36.54 & 8.87 & & & & & 0.835 & 0.024 & 0.419 & 0.738 \\
\hline $\begin{array}{l}\text { commitment } \\
\text { Normative }\end{array}$ & 36.79 & 8.19 & & & & & & 0.726 & 0.063 & 0.523 \\
\hline $\begin{array}{c}\text { commitment } \\
\text { Organisational }\end{array}$ & 33.58 & 8.45 & & & & & & & 0.759 & 0.742 \\
\hline $\begin{array}{l}\text { commitment } \\
\text { Notes: } \\
\text { For correlations } \\
\text { Reliabilities app }\end{array}$ & $\begin{array}{l}106.92 \\
>0.15 \\
\text { ear in the }\end{array}$ & $\begin{array}{l}17.09 \\
+0.05 \\
\text { liagonal }\end{array}$ & & & & & & & & 0.795 \\
\hline
\end{tabular}




\begin{tabular}{|c|c|c|c|c|}
\hline \multirow{2}{*}{$\begin{array}{l}\text { Albert Caruana and } \\
\text { Peter Calleya } \\
\text { The effect of internal } \\
\text { marketing on organisational } \\
\text { commitment among retail } \\
\text { bank managers }\end{array}$} & \multicolumn{4}{|c|}{$\begin{array}{l}\text { Table III } \\
\text { Factor analysis of the items making up the } \\
\text { organisational commitment scales }\end{array}$} \\
\hline & \multirow[b]{2}{*}{ Item } & \multicolumn{3}{|c|}{ Organisational commitment dimensions } \\
\hline \multirow{25}{*}{$\begin{array}{l}\text { International J ournal of } \\
\text { Bank Marketing } \\
16 / 3 \text { [1998] 108-116 }\end{array}$} & & $\begin{array}{c}\text { Affective } \\
\text { commitment }\end{array}$ & $\begin{array}{l}\text { Continuance } \\
\text { commitment }\end{array}$ & $\begin{array}{l}\text { Normative } \\
\text { commitment }\end{array}$ \\
\hline & $\overline{Q 16}$ & 0.73575 & 0.02310 & 0.14222 \\
\hline & Q17 & 0.69768 & 0.03857 & 0.11803 \\
\hline & Q18 & 0.65987 & 0.03009 & 0.28893 \\
\hline & Q19R & 0.27328 & 0.04928 & 0.16627 \\
\hline & Q20R & 0.71798 & -0.03495 & -0.10153 \\
\hline & Q21R & 0.73136 & -0.01848 & 0.11669 \\
\hline & Q22 & 0.73713 & -0.02795 & 0.20815 \\
\hline & Q23R & 0.68460 & -0.08049 & 0.03545 \\
\hline & Q24R & 0.33526 & 0.47127 & -0.03807 \\
\hline & Q25 & -0.03511 & 0.70944 & 0.05663 \\
\hline & Q26 & 0.14955 & 0.62372 & 0.01187 \\
\hline & Q27R & -0.09013 & 0.32614 & -0.04320 \\
\hline & Q28 & -0.04353 & 0.60800 & -0.06743 \\
\hline & Q29 & -0.12695 & 0.65917 & 0.04660 \\
\hline & Q30 & -0.05725 & 0.60493 & 0.18155 \\
\hline & Q31 & 0.05422 & 0.60771 & -0.12725 \\
\hline & Q32 & -0.02441 & 0.39421 & 0.43994 \\
\hline & Q33R & 0.43160 & -0.08854 & 0.20298 \\
\hline & Q34R & 0.22410 & -0.14451 & 0.48758 \\
\hline & Q35 & 0.26057 & -0.04707 & 0.78283 \\
\hline & Q36 & 0.21827 & -0.08655 & 0.65825 \\
\hline & Q37 & 0.15037 & 0.03040 & 0.77450 \\
\hline & Q38 & -0.07725 & 0.18720 & 0.72657 \\
\hline & Q39R & 0.27427 & -0.05321 & 0.38015 \\
\hline
\end{tabular}

provided and they are all owed to partici pate in decisions about their work (Allen and Meyer, 1990). The identification of these variables as antecedents rai ses the question as to whether inter nal marketing is indeed a separate construct or, as suggested by Hales (1994), it merely represents the relabelling of existing human resources management practices. There is little doubt that at this point the distinction between inter nal marketing and human resources practices begins to blur. Thus the three factors identified as part of the internal marketing construct can be seen to be reflected in some of these antecedents. Vision appears to be closely related to clear goals, some of the aspects treated under the dimension of development have to do with feedback and a challenging job, and the i tems that make up the reward dimension are related to cl ear roles and equitabl etreatment. These findings appear to underline the point that internal marketing may be doing nothing beyond underlining the need for individuals who nor mally perform the human resources function to be also market oriented.

The limitati ons of the study are fairly selfevident. The internal marketing construct requires further theoretical development and elaboration to distinguish it from some of the constructs that are described and nor mally treated as part of human resource management. In tur $n$ this may point to the need for the improvement of the inter nal marketing instrument and further aspects of validity need to be consi dered. Finally, the results of this study come only from the managerial grades of one organisation - a retail bank, and in this respect any generalisations must be done with care.

Further elaboration and clearer boundary setting for the internal marketing construct could provide an opportunity for more research that could look at extending inter nal marketing beyond service firms to organisations that market physical products. An important characteristic of services is intangibility. However intangibility is not an absolute but can be thought of as a conti nuum and any product offering is to some degree physical and service (Shostack, 1982). Thus even product offerings that are nor mally considered as physical products such as bottles of soda al so include a consi derable degree of service. Indeed to a large extent the distribution function for physical products is a

$\overline{\text { Table IV }}$

Results of regressions between organisational commitment and internal marketing and their dimensions

\begin{tabular}{lcccc}
\hline $\begin{array}{l}\text { Independent } \\
\text { variable }\end{array}$ & $\begin{array}{c}\text { Organisational } \\
\text { commitment }\end{array}$ & $\begin{array}{c}\text { Organisational } \\
\text { commitment }\end{array}$ & $\begin{array}{c}\text { Affective } \\
\text { commitment }\end{array}$ & $\begin{array}{c}\text { Affective } \\
\text { commitment }\end{array}$ \\
\hline Adj $R^{2}$ & 0.185 & 0.189 & 0.305 & 0.310 \\
F & $39.535^{\mathrm{a}}$ & $14.187^{\mathrm{a}}$ & 75.772 & $26.458^{\mathrm{a}}$ \\
Beta - Internal market & $0.325^{\mathrm{a}}$ & - & $0.556^{\mathrm{a}}$ & - \\
$\quad$ Fac - reward & - & $0.198^{\mathrm{b}}$ & - & $0.315^{\mathrm{a}}$ \\
$\quad$ Fac - development & - & $0.345^{\mathrm{a}}$ & - & $0.426^{\mathrm{a}}$ \\
$\quad \mathrm{Fac}-$ vision & - & $0.212^{\mathrm{b}}$ & - & $0.204^{\mathrm{b}}$ \\
Age $\quad \mathrm{ns}$ & $\mathrm{ns}$ & $\mathrm{ns}$ & $\mathrm{ns}$ \\
Gender & $\mathrm{ns}$ & & $\mathrm{ns}$ & $\mathrm{ns}$ \\
Notes: & & & & \\
a $p>0.001 ; \mathrm{b} p>0.01 ; \mathrm{ns}=$ not significant & & &
\end{tabular}


Albert Caruana and

Peter Calleya

The effect of internal marketing on organisational commitment among retail bank managers

International Journal of

Bank Marketing

16/ 3 [1998] 108-116 service. Thus although the concept of internal marketing tends to be seen as being appropriate to service firms it may have applications beyond this and may also be valid for firms in the consumer and industrial sectors. Ir respective of whether a firm markets physical or service products, it seems important that they practi se external marketing and inter nal marketing that results in effective interactive marketing that enables the successful buil ding of l ong-term and profitable relati onshi ps with customers.

\section{References}

Allen, N.J . and Meyer, J .P. (1990), "The measurement and antecedents of affective, continuance and nor mative commitment to the organization", J ournal of Occupational Psychology, Vol. 63, pp. 1-18.

Armstronq, I.S. and Overton, T. S. (1977), "Estimating non-response bias in mail surveys", J ournal of Marketing Research, August, pp. 396-402.

Bateson, J .E.G. (1991), Managing Services Marketing, 2nd ed., Dryden Press, Fort Worth, TX.

Becker, H.S. (1960), "Notes on the concept of commitment", American I ournal of Sociology, Vol. 66, pp. 32-42.

Berry, L.L. (1981), "The employee as customer", J ournal of Retail Banking, Vol. 3No. 1, March, pp. 33-9.

Berry, L.L., Conant, J .S. and Parasuraman, A. (1991), “A framework for conducting a service marketing audit", J ournal of the Academy of Marketing Science, Vol. 19, Summer, pp. 255-68.

Ber ry, L.L. and Parasuraman, A . (1991), Marketing of Services - Competing through Quality, Macmillan, New York, NY.

Caruana, A., Ramaseshan, B. and Ewing, M.T. (1997), “Does a market orientation affect organisati onal commitment?", in Harrison, J . and Nicholls, M.G. (Eds), I nnovation - New Products, Process and Techniques, Part II, pp. 815-7, Decision Sciences Institute, Fourth Inter nati onal Meeting, Sydney, 20-23J uly.

Carman, J.M. (1990), “Consumer perceptions of service quality: an assessment of the SERVQUAL dimensions", J ournal of Retailing, Vol. 66 No. 1, Spring, pp. 33-55.

Cronbach, L.J . (1951), “Coefficient al pha and the internal structure of tests", Psychometrika, Vol. 16 No. 3, September, pp. 297-333.

Donnelly, J.H.J r., Berry, L.L. and Thompson, T.W. (1985), Marketing Financial Services: A Strate gic Vision, Dow J ones I rwin, Homewood, IL, pp. 229-45.

Dunham, R.B., Grube, J A. and Castaeda, M.B. (1994), "Organizational commitment: the utility of an integrative definition", J ournal of Applied Psychology, Vol. 79 No. 3, pp. 370-80

Fisk, R.P., Brown, S.W. and Bitner, M.J . (1993), "Tracking the evolution of the services marketing literature", J ournal of Retailing, Vol. 69No. 1, pp. 61-103.
George, W.R. (1990), “Internal marketing and organizational behavior: a partnership in devel oping customer-conscious employees at every level", J ournal of Business Research, Vol. 20 No. 1, J anuary, pp. 63-70.

George, W.R. and Grönross, C. (1989), “Developing customer conscious employees at every level internal marketing", in Congram, C.A. and Friedman, M.L. (Eds), Handbook of Services Marketing, AMACOM, New York, NY.

Gremler, W.E., Bitner, M.J . and Evans, K.R. (1994), "The inter nal service encounter", International J ournal of Servicel ndustry Manage ment, Vol. 5 No. 2, pp. 34-56.

Grönross, C. (1981), “Internal marketing an integral part of marketing theory", in Donnelly, J.H.J r. and George, W.R. (Eds), Marketing of Services, Proceedings of the American Marketing A ssociation.

Grönross, C. (1984), "A service quality model and its marketing implications", European J ournal of Marketing, Vol. 18 No. 4, pp. 36-44.

Hackett, R.D., Bycio, P. and Hausdorf, P. A. (1994), “Further assessment of Meyer and Allen's (1991) three component model of organizational commitment", J ournal of Applied Psychology, Vol. 79 No. 1, pp. 15-23.

Hales, C. (1994), “Internal marketing as an applicati on to human resources management", Human Resources ManagementJ ournal, Vol. 5 No. 1, pp. 50-71.

Hogg, C. (1996), "Selling your soul”, Human Resources, Vol. 96 No. 25, pp. 88-90.

Hrebiniak, L.G. and Alutto, J .A. (1972), “Personal and role-related factors in the development of organizational commitment", Administrative ScienceQuarterly, Vol. 17, pp. 555-73.

J aworski, B.J . and Kohli, A.K. (1993), “M arketing orientation: antecedents and consequences, J ournal of Marketing, Vol. 57, J uly, pp. 53-70.

Jenkins, M. and Thomlinson, P.P. (1992), “Organisational commitment and job satisfaction as predictors of employee tur nover intentions", Management Research News, Vol. 15 No. 10, pp. 18-22.

Kotler, P. (1991), Marketing Management - Analysis, Planning, I mplementation and Control, 7th ed., Prentice Hall, Englewood Cliffs, NJ.

Lovelock, C.H. (1983), “Classifying services to gain strategic marketing insights", J ournal of Marketing, Vol. 47 No. 3, Summer, pp. 9-20.

Mathieu, J .E. and Zajac, D.M. (1990), "A review and meta-analysis of the antecedents, correlates and consequences of organisational commitment", Psychological Bulletin, Vol. 108 No. 2, pp. 171-94.

Meyer, I .P. and Allen, N.J . (1984), "Testing the 'si de-bet theory' of organizati onal commitment: some methodological considerations", J ournal of Applied Psychology, Vol. 69, pp. 372-8.

Meyer, J .P. and Allen, N.J . (1990), “The measurement and antecedents of affective, continuance and nor mative commi tment to the organization", J ournal of Occupational Psychology, Vol. 63, pp. 1-18. 
Albert Caruana and

Peter Calleya

The effect of internal marketing on organisational commitment among retail bank managers

International J ournal of Bank Marketing 16/3 [1998] 108-116
Meyer, I .P. and Allen, N.I . (1991), "A three-component conceptualization of organizational commitment: some methodological considerations", Human Resources Management Review, Vol. 1, pp. 61-89.

Money, A.H. and Foreman, S. (1996), "The measurement of internal marketing: a confirmatory case study", J ournal of Marketing Management, Vol. 11 No. 8, November, pp. 755-66.

Nunnally, J .C. (1978), Psychometric Theory, 2nd ed., McGraw Hill, New York, NY.

Porter, L., Steers, R., Mowday, R. and and Boulian, P. (1974), “Organisational commitment, job satisfaction and turnover among psychiatric technicians", I ournal of Applied Psychology, Vol. 59, pp. 603-09.

Rafiq, M. and A hmed, P.R. (1993), "Scope of internal marketing: defining the boundary between marketing and human resources management", J ournal of Marketing Manage ment, J uly, Vol. 9 No. 3, pp. 219-32.

Richardson, B.A. and Robinson, C.G. (1986), "The impact of inter nal marketing on customer service in a retail bank", International J ournal of Bank Marketing, Vol. 4No. 5, pp. 3-30.

Ritzer, G. and Trice, H.M. (1969), "An empirical study of Howard Becker's side bet theory", Social Forces, Vol. 47, pp. 475-9.

Rosenblunth, H. and Peters, D. (1992), TheCustomer Comes Second: and Other Secrets of
Exceptional Service, William M orrow and Co., New York, NY.

Sasser, W.E. (1976), "Match supply and demand in service industries", Harvard Business Review, Vol. 54 No. 3, November-December, pp. 133-40.

Sasser, W.E. and Arbeit, S.P. (1980), "Selling jobs in the service sector", Business Horizons, Vol. 23 No. 1, J anuary-February, pp. 58-9.

Shostack, G.L. (1977), "Breaking free from product marketing", J ournal of Marketing, Vol. 41, April, pp. 73-80.

Siguaw, J .A., Brown, G.R. and Robert, T. (1994), "The influence of the market orientation of the firm on the sales force behavi or and attitudes", J ournal of Marketing Research, Vol. 31 No. 1, pp. 106-16.

Schlessenger, L.A. and Heskett, J .L. (1991), "Breaking the cycle of failure in services", Sloan Management Review, Vol. 32 No. 3, pp. 17-28.

Tansuhaj, P., Randall, D. and McCullough, J. (1991), "Applying the internal marketing concept within large organizations: as applied to a Credit Union", J ournal of Professional Services Marketing, Vol. 6 No. 2, pp. 193-202.

Tansuhai, P., Wonq, I . and McCullough, I . (1987), "Internal and external marketing: effect on customer satisfaction in banks in Thailand", International J ournal of Bank Marketing, Vol. 5No. 3, pp. 73-83.

Appendix. Mean and standard deviations for instruments and scale items used

$\overline{\text { Table Al }}$

\begin{tabular}{|c|c|c|}
\hline Internal marketing scale & Mean & Std dev \\
\hline \multicolumn{3}{|l|}{ Vision } \\
\hline 1. Our organisation offers employees a vision that they can believe in & 3.78 & 1.38 \\
\hline 2. We communicate our organisation's vision well to employees & 3.59 & 1.36 \\
\hline \multicolumn{3}{|l|}{ Development } \\
\hline 3. We prepare our employees to perform well & 4.46 & 1.30 \\
\hline $\begin{array}{l}\text { 4. Our organisation views the development of knowledge and skills in employees as } \\
\text { an investment rather than a cost }\end{array}$ & 4.77 & 1.55 \\
\hline $\begin{array}{l}\text { 5. Skill and knowledge development of employees happens as an ongoing process } \\
\text { in our organisation }\end{array}$ & 4.74 & 1.44 \\
\hline 6. We teach our employees "why they should do things" and not just "how they & & \\
\hline should do things" & 3.95 & 1.52 \\
\hline 7. In our organisation we go beyond training and educate employees as well & 3.73 & 1.46 \\
\hline 13. In this organisation, the employees are properly trained to perform their service roles & 4.25 & 1.46 \\
\hline $\begin{array}{l}\text { 14. This organisation has the flexibility to accommodate the differing needs of employees } \\
\text { 15. We place considerable emphasis in this organisation on communicating with our }\end{array}$ & 3.71 & 1.47 \\
\hline employees & 3.35 & 1.26 \\
\hline Reward & & \\
\hline $\begin{array}{l}\text { 8. Our performance measurement and reward systems encourage employees to work } \\
\text { together }\end{array}$ & 2.87 & 1.45 \\
\hline $\begin{array}{l}\text { 9. We measure and reward employee performance that contributes most to our } \\
\text { organisation's vision }\end{array}$ & 2.72 & 1.44 \\
\hline $\begin{array}{l}\text { 10. We use data we gather from employees to improve their jobs, and to develop the } \\
\text { strategy of the organisation }\end{array}$ & 3.28 & 1.43 \\
\hline 11. Our organisation communicates to employees the importance of their service roles & 3.80 & 1.55 \\
\hline $\begin{array}{l}\text { 12. In our organisation, those employees who provide excellent service are rewarded for } \\
\text { their efforts }\end{array}$ & 2.98 & 1.60 \\
\hline
\end{tabular}


Albert Caruana and

Peter Calleya

The effect of internal marketing on organisational

commitment among retail

bank managers

International Journal of

Bank Marketing

16/ 3 [1998] 108-116 $\overline{\text { Table All }}$

Commitment scale

Mean Std dev

Affective commitment

1. I would be very happy to spend the rest of my career with this organisation

4.88

1.55

2. I enjoy discussing my organisation with people outside of it

$4.57 \quad 1.66$

3. I really feel as if this organisation's problems are my own

$4.75 \quad 1.73$

4. I think that I could easily become as attached to another organisation as I am to this one $(R)$

$4.16 \quad 1.58$

5. I do not feel like "part of the family" at my organisation (R)

$4.43 \quad 1.65$

6. I do not feel "emotionally attached" to this organisation (R)

$4.44 \quad 1.72$

7. This organisation has a great deal of personal meaning for me

$\begin{array}{ll}4.44 & 1.72 \\ 4.77 & 1.56\end{array}$

8. I do not feel a strong sense of belonging to my organisation (R)

4.85

1.57

Continuance commitment

9. I am not afraid of what might happen if I quit my job without having another one lined up ( $R$ )

$5.05 \quad 1.89$

10. It would be very hard for me to leave my organisation right now, even if I wanted to

11. Too much in my life would be disrupted if I decided I wanted to leave my organisation now

12. It wouldn't be too costly for me to leave my organisation now (R)

13. Right now, staying with my organisation is a matter of necessity as much as desire

14. I feel that I have too few options to consider leaving this organisation (R)

$4.22 \quad 1.72$

15. One of the few serious consequences of leaving this organisation would be the scarcity of available alternatives

$4.14 \quad 1.73$

16. One of the major reasons I continue to work for this organisation is that leaving would require considerable personal sacrifice - another organisation may not match the overall benefits I have (R)

$4.78 \quad 1.67$

Normative commitment

17. I think that people these days move from company to company too often

18. I do not believe that a person must always be loyal to his or her organisation (R)

$4.22 \quad 1.44$

$5.75 \quad 1.74$

$3.84 \quad 1.58$

20. One of the major reasons I continue to work for this organisation is that I believe that loyalty is important and therefore feel a sense of moral obligation to remain

21. If I got another offer for a better job elsewhere I would not feel it was right to leave my organisation

22. I was taught to believe in the value of remaining loyal to one organisation

$4.14-1.88$

$3.22 \quad 1.67$

$3.99 \quad 1.91$

23. Things were better in the days when people stayed with one organisation for most of their careers

$3.58 \quad 1.76$

24. I do not think that wanting to be a "company man" or "company woman" is sensible anymore (R) 